\title{
BODY COMPOSITION COMPARISON IN TWO ELITE FEMALE WHEELCHAIR ATHLETES
}

By L. Lussier, M.D., Ph.D., J. Knight, M.S., G. Bell, Ed.D., R.P.T., A.T.C., T. Lohman, Ph.D., A. F. Morris, Ph.D., F.A.C.S.M. ${ }^{1}$ Division of Rehabilitation Education and Department of Physical Education, University of Illinois, Urbana-Champaign, Illinois 61820, U.S.A.

Summary. It was the purpose of this study to determine body composition by two methods in two excellent female athletes. One sportswoman (SRH) was national wheelchair marathon champion in 1977 in 3 hours, 40 minutes on the Boston course. She still competes internationally and has won three gold medals and set three world records in the last Olympiad for the handicapped in I980. The second woman athlete (LSJ) competes in wheelchair basketball and track on a national level. Body density was determined by the standard underwater weighing procedure and residual volume determination. A second method to calculate cellular body mass was the measure of potassium $40(40 \mathrm{~K})$ activity by whole body scintillation counter. The characteristics of these athletes are listed as follows:

\begin{tabular}{cccccc}
\hline Subject & Age & $\begin{array}{c}\text { Weight } \\
(\mathrm{kg})\end{array}$ & $\begin{array}{c}\text { Height }(\mathrm{cm}) \\
\text { sitting }\end{array}$ & $\begin{array}{c}{ }_{\mathrm{o}} \mathrm{Fat} \\
4 \mathrm{OK}\end{array}$ & $\begin{array}{c}{ }_{\mathrm{o}} \mathrm{Fat} \\
\left(\mathrm{H}_{2} \mathrm{O}\right)\end{array}$ \\
\hline $\mathrm{I}$ & 25 & $50 \cdot 8$ & 87.8 & $29 \cdot 49$ & $28 \cdot 94$ \\
2 & 27 & $60 \cdot 8$ & $84 \cdot 2$ & $3 \mathrm{I} \cdot \mathrm{I} 2$ & $32 \cdot 08$ \\
\hline
\end{tabular}

The results show that both methods of determining adiposity produce results differing by only one percentage point. It is important to determine body composition in these wheelchair athletes since their cellular body mass is decreased because of their disability.

Key words: Female paraplegic athletes; Wheelchairs; Body composition.

\section{Introduction}

BoDy composition determination is commonly utilized to describe and compare various groups of athletes, as part of the athletic profile (Vaccaro et al., I 98I ). This body composition determination provides an estimation of lean body mass, including muscle mass and other cellular components, as well as bone and connective tissue mass. The proportions and density of these components may vary as a function of age, sex, and activity. The significance and interpretation of body composition determinations is still controversial (McArdle et al., I98I).

Individuals who have suffered spinal injuries and are confined to wheelchairs demonstrate loss of muscle mass, changes in cardiovascular responses

\footnotetext{
${ }^{1}$ Address for correspondence and reprints: A. F. Morris, University of Illinois, Division of Rehabilitation Education, Rehabilitation Education Center, I207 South Oak Street, Champaign, Illinois 61820, U.S.A.
} 
below the level of injury, and connective tissue changes associated with the absence of weight bearing on the lower limbs (Cohn et al., I 980). These changes will have an impact on body water, bone density and muscle mass of the lower limbs. Interpretation of body composition estimations in this population will require a new set of standards.

Individuals confined to wheelchairs cannot afford excess weight, since this may predispose them to pressure ulcers and other skin and soft tissue damage. In addition, wheelchair dependent individuals need to maintain an adequate muscle mass for transfers and for other activities of daily living. There are presently no guidelines or standards for assessment and prescription of weight loss for the population of spinal injured individuals. This topic of body composition may become significant for wheelchair athletes, who, like their able-bodied counter-parts, seek to optimize their athletic performance.

\section{Purpose}

Since very little is known concerning body composition of the female wheelchair athlete, this preliminary study was undertaken to compare different methods of determining their body composition. Hydrostatic weighing was compared and contrasted with whole body potassium $40(40 \mathrm{~K})$ counting technique and with skinfold determinations. A measurement of bone density was also obtained using the ulna and radius.

\section{Methods}

Subjects

Two female athletes at a Big Ten school agreed to serve as subjects for this preliminary study. Each subject expressed understanding of the experimental procedures by reading and signing statements of informed consent. The protocol and methodology of this study were approved by the Medical Human Subjects Committee of the University of Illinois. The subjects' descriptive characteristics are listed in Table I.

TABLE I

Descriptive characteristics of athletes

\begin{tabular}{lcc}
\hline & \multicolumn{2}{c}{ Subjects } \\
& I & 2 \\
\hline Age & 25 & 27 \\
Ht (Approx.) $(\mathrm{cm})$ & I75.3 & I77.8 \\
Sitting Ht (cm) & $87 \cdot 8$ & $84 \cdot 2$ \\
Weight (kg) & $50 \cdot 8$ & $60 \cdot 8$ \\
Level of injury & T5-6 (Incomplete) & T5 \\
& TI 2-LI (Functional) & I969 (I6 years) \\
Date SCI (Age) & I966 (9 years) & I \\
Classification: & & II \\
Basketball & II & IV \\
Other & &
\end{tabular}


Body potassium assessment

Body potassium was determined by counting whole body potassium 40 (40K). Naturally occurring $40 \mathrm{~K}$ Gamma radiation was measured in a $4 \pi$ liquid scintillation whole body counter (Twardock et al., I966). Each subject was counted for two consecutive three-minute periods, with three minute background counts taken immediately following each subject count. Fatfree body weight (FFW) and total body potassium were computed from the $40 \mathrm{~K}$ measurement according to Boileau et al., (I973).

\section{Measurement of body density}

Body density $\left(\mathrm{D}_{\mathrm{b}}\right)$ was measured by underwater weighing using the procedures and instrumentation for the measurement of underwater weight, as modified according to those suggested by Akers and Buskirk (1969). Underwater weight is measured on a weighing platform (LVDT force transducers upon which the weighing platform rests (Daytronic Corp., Model I 52A-25, Hewlett-Packard, Model 7I23A) at the end of a forced expiration just prior to the functional pulmonary residual volume measurement, instantaneous with underwater weight (closed-circuit $\mathrm{O}_{2}$ dilution method modified from Wilmore (I969), Med. Sciences Model 505). After several practice trials, three separate determinations were made on each subject, and the average value used as the criterion score.

\section{Bone mineral measurement}

All bone mineral measurements were made by a direct photon absorption method (Cameron \& Sorenson, I963) using a Norland-Cameron Bone Mineral Analyzer. The instrument is designed to measure bone width $(\mathrm{cm})$ as well as mineral content $(\mathrm{gm} / \mathrm{cm})$.

\section{Anthropometric measurements}

The anthropometric dimensions which were taken included nine skinfolds, six body circumferences, and six skeletal diameters. Three series of measurements were obtained. All skinfold thickness measurements were made with a Harpenden Caliper on the right side of the body. Circumferences were made with a steel tape, and diameters with a Harpenden Anthropometer.

\section{Results}

The specific skinfolds (as described by Allen et al., I956; Behnke \& Wilmore, I974) are reported in Table II. The selected anthropometric measurements, including circumferences and diameters, are listed in Table III.

Results from the body density and $40 \mathrm{~K}$ determinations are reported in Table IV. Estimation of body composition, as measured by both techniques, was approximately the same. On the other hand, prediction 
TABLE II

Skinfold measurements

(Sum of nine sites)

\begin{tabular}{lcr}
\hline \multicolumn{1}{c}{ Skinfolds } & \multicolumn{2}{c}{ Subjects } \\
& I & \multicolumn{1}{c}{2} \\
\hline Triceps & $9 \cdot 7$ & I6.5 \\
Biceps & $4 \cdot 0$ & $7 \cdot 0$ \\
Subscapular & $8 \cdot 2$ & I $3 \cdot 9$ \\
Midaxillary & $6 \cdot \mathrm{I}$ & I0.2 \\
Supra-iliac (Waist) & $9 \cdot 8$ & I6.3 \\
Supra-iliac (Ant.) & I I.9 & I $4 \cdot 6$ \\
Abdomen & I4.2 & I $5 \cdot 3$ \\
Thigh & I $8 \cdot 9$ & $28 \cdot 8$ \\
Medial Calf & I $8 \cdot 5$ & $24 \cdot 2$ \\
Sum of 9 Skinfolds $=$ & I00.4 & I $46 \cdot 8$ \\
\hline
\end{tabular}

TABLE III

Selected anthropometric measurements

\begin{tabular}{lcclrr}
\hline & \multicolumn{2}{c}{ Subjects } & & \multicolumn{2}{c}{ Subjects } \\
\cline { 2 - 6 } $\begin{array}{l}\text { Circumferences } \\
(\mathrm{cm})\end{array}$ & $\mathrm{I}$ & 2 & Diameters $(\mathrm{cm})$ & I & 2 \\
\hline Upper Arm & $28 \cdot 8$ & $30 \cdot 0$ & Shoulder & $40 \cdot 2$ & $39 \cdot 7$ \\
Forearm & $24 \cdot 2$ & $25 \cdot 2$ & Hip & $26 \cdot 0$ & $28 \cdot 9$ \\
Mid Thigh & $36 \cdot \mathrm{I}$ & $46 \cdot 0$ & Chest & $24 \cdot 7$ & $29 \cdot 0$ \\
Calf & $24 \cdot 5$ & $32 \cdot 5$ & Wrist & $5 \cdot 3$ & $5 \cdot 0$ \\
Chest & $78 \cdot 5$ & $86 \cdot 8$ & Knee & $8 \cdot 4$ & $9 \cdot 4$ \\
Abdomen & $65 \cdot 6$ & $74 \cdot 5$ & Ankle & $6 \cdot 8$ & $6 \cdot 6$ \\
\hline
\end{tabular}

TABLE IV

Body composition: body density and $40 \mathrm{~K}$ determinations

\begin{tabular}{lrr}
\hline & \multicolumn{2}{c}{ Subjects } \\
& \multicolumn{1}{c}{ I } & \multicolumn{1}{c}{2} \\
\hline Residual volume (litres) & $\mathrm{I} \cdot \mathrm{I} 767$ & $\mathrm{I} \cdot \mathrm{I} 002$ \\
Body density & $\mathrm{I} \cdot 03 \mathrm{I} 3$ & $\mathrm{I} \cdot 0240$ \\
$\%$ Fat $\left(\mathrm{D}_{\mathrm{b}}\right)$ & $28 \cdot 94$ & $32 \cdot 08$ \\
$\%$ Fat $(40 \mathrm{~K})$ & 29.49 & $3 \mathrm{I} \cdot \mathrm{I} 2$ \\
Fat Wt $(\mathrm{kg})$ & $\mathrm{I} 4.70$ & $\mathrm{I} 9 \cdot 50$ \\
Fat free Wt $(\mathrm{kg})$ & 35.93 & $4 \mathrm{I} \cdot 29$ \\
\hline
\end{tabular}


TABLE V

Body composition: body density and body fatness estimates from prediction equations

\begin{tabular}{|c|c|c|c|c|}
\hline & \multicolumn{2}{|c|}{ Body density $\left(\mathrm{gm} / \mathrm{cm}^{3}\right)$} & \multicolumn{2}{|c|}{$\begin{array}{c}\text { "' Body fatness } \\
\text { (Brozek et al., I } 963 \text { ) }\end{array}$} \\
\hline & \multicolumn{2}{|c|}{ Subjects } & \multicolumn{2}{|c|}{ Subjects } \\
\hline & I & 2 & I & 2 \\
\hline Sloan et al., I962 & $\mathrm{I} \cdot 058$ & $I \cdot 050$ & $17 \cdot 7$ & $2 \mathrm{I} \cdot \mathrm{O}$ \\
\hline Wilmore \& Behnke, I970 & I $\cdot 048$ & I $\cdot 039$ & $21 \cdot 9$ & $25 \cdot 5$ \\
\hline Katch \& McArdle, I973 & $1 \cdot 058$ & I $\cdot 044$ & $17 \cdot 7$ & $23 \cdot 5$ \\
\hline
\end{tabular}

TABLE VI

Bone width and density of upper extremity

\begin{tabular}{|c|c|c|c|c|}
\hline \multirow[b]{2}{*}{ Bone Density $(\mathrm{g} / \mathrm{cm})$} & \multicolumn{3}{|c|}{$\begin{array}{l}\text { Wheelchair } \\
\text { athletes (2) }\end{array}$} & \multirow{2}{*}{$\begin{array}{c}\begin{array}{c}\text { Normal female } \\
\text { controls }(7)\end{array} \\
\overline{\mathrm{x}}\end{array}$} \\
\hline & I & 2 & $\overline{\mathrm{x}}$ & \\
\hline Radius & $\mathrm{I} \cdot \mathrm{OI}$ & $\mathrm{I} \cdot \mathrm{O} 4$ & $I \cdot 025$ & $0 \cdot 87$ \\
\hline Ulna & $\mathrm{I} \cdot 06$ & 0.96 & $\mathrm{I} \cdot \mathrm{OI}$ & 0.80 \\
\hline \multicolumn{5}{|l|}{ Bone Width $(\mathrm{cm})$} \\
\hline Radius & $\mathrm{I} \cdot 45$ & $\mathrm{I} \cdot 48$ & $I \cdot 465$ & $I \cdot 23$ \\
\hline Ulna & $\mathrm{I} \cdot 27$ & $\mathrm{I} \cdot 34$ & $\mathrm{I} \cdot 305$ & $\mathrm{I} \cdot \mathrm{I} 7$ \\
\hline
\end{tabular}

of body density from selected skinfold equations is conflicting. See Table $\mathrm{V}$.

Mean bone densities of the radius and ulna, obtained from a sample of seven able-bodied White females of comparable ages (mean-2 I years, range of I9-30 years) were $0.87 \mathrm{~g} / \mathrm{cm}$, and $0.80 \mathrm{~g} / \mathrm{cm}$. These normal women had mean bone widths of $\mathrm{I} \cdot 23 \mathrm{~cm}$ for the radius, and $\mathrm{I} \cdot \mathrm{I} 7 \mathrm{~cm}$ for the ulna. The female wheelchair athletes show a higher bone density in the radius, with a mean of $\mathrm{I} \cdot 025 \mathrm{~g} / \mathrm{cm}$, and a mean of $\mathrm{I} \cdot \mathrm{OI}_{\mathrm{I}}$ for the bone density of the ulna. Mean bone width of these disabled female athletes was I.465 for the radius, and $\mathrm{I} \cdot 305$ for ulna. These values may be seen in Table VI. It is important to note that these values for the female athletes are higher than their able-bodied counterparts.

Upon physical examination of these wheelchair athletes, it was observed that the size of their lower limbs was diminished, as contrasted to their able-bodied counterparts. However, perhaps due to extended use of the upper extremities, the radius and ulna were somewhat larger in the wheelchair athletes.

\section{Discussion and Conclusions}

The measurements of body composition obtained by densitometry and $40 \mathrm{~K}$ counting yielded similar estimates for each of the two female wheelchair athletes. The body fatness is greater than that predicted by the sum of 
nine skinfolds (I00.4 $\mathrm{mm}$ with Subject I, and I $46.8 \mathrm{~mm}$ for Subject 2 ). Skinfold measurements would suggest a larger difference in body fatness between the two athletes, not as well reflected in densitometry and $40 \mathrm{~K}$ counting. Part of the difference may be related to the age of injury which occurred before puberty for Subject I, and after puberty for Subject 2 . Bone densities of the lower limb would have been useful if the instrumentation had permitted their measurement. Upper limb bone mineral content and bone width appear increased in these two females and may be attributed to the use of the upper limbs for weight bearing in transfers, and because of their extensive involvement in wheelchair sports. Decreased muscle mass in the lower limbs is demonstrated by the smaller circumferences in spite of possible oedema of the lower extremities, due to gravity and the absence of the muscle venous pump.

This report represents a first attempt to quantify the body composition of spinal cord injured individuals. Further investigation is needed to interpret body density estimations for such individuals. Furthermore, the level of the injury, as well as the date of occurrence may affect overall muscle mass and connective tissue composition. Moreover, body-water distribution may need to be taken into account, as this may differ between populations of tetraplegic, quadriplegics and high and low paraplegic individuals. Certainly more research needs to be done in this area.

\section{RÉSUMÉ}

Cette étude visait à determiner la composition corporelle de deux excellentes athletes feminines. Une athlete (SRH) était chapionne nationalle an chaise roulante au marathon de Boston de 1977, avec un temps de 3 hres. $40 \mathrm{~min}$. Elle demeure en competition au niveau internationalle et a mérité trois medailles d'or er réduit trois marques mondiales aux Olympiades pour handicappés in I980. La deuxieme athlete femine (LSJ) est membre de l'équipe nationalle de basketball et participe aux competitions de piste. Leur densité corporelle jut determinée par la méthode standard de pesée hydrostatique avec mesure du volume résiduel. Une deuxieme méthode fut de mesurer l'activité du potassium 40 (40K) du corps entier par scintillateur liquide. Les caracteristiques de ces athletes sont les suivantes:

\begin{tabular}{cccccc}
\hline Sujet & Age & Poids $(\mathrm{kg})$ & $\begin{array}{c}\text { Taille }(\mathrm{cm}) \\
\text {-assise }\end{array}$ & $\begin{array}{c}{ }_{0}{ }_{0} \text { Adiposité } \\
40 \mathrm{~K}\end{array}$ & $\begin{array}{c}{ }_{0}{ }_{0} \text { Adiposité } \\
\left(\mathrm{H}_{2} \mathrm{O}\right)\end{array}$ \\
\hline $\mathrm{I}$ & 25 & $50 \cdot 8$ & $87 \cdot 8$ & $29 \cdot 49$ & $28 \cdot 94$ \\
2 & 27 & $69 \cdot 8$ & $84 \cdot 2$ & $3 \mathrm{I} \cdot \mathrm{I2}$ & $32 \cdot 08$ \\
\hline
\end{tabular}

Les resultats indiquent que ces deux méthodes de détermination de l'adiposité ont produit des données similaires, avec une difference de seulement un purcent. Les est important do determiner la composition corporelle de ces athletes en chaise roulante, qui ont une masse cellulaire corporelle reduite à cause de leur handicap.

\section{ZUSAMMENFASSUNG}

Der Zweck dieser Studie war, die Körperzusammensetzung zweier susgezeichneter Athletinnen aufgrund zweier Methoden festzustellen. Eine dieser Sportlerinnen (SRH) war in 1977 die Siegerin im National-Marathon-Wettkampf, den sie in 3 Stunden und 40 Minuten auf der Rennbahn in Boston errang.

Sie nimmt immer noch an internationalen Wettkämpfen teil, hat drei Gokdmedaillen 
gewonnen und in der letzten Olympiade Für Körperbehinderte in I 980 drei neue Weltrekorde aufgestellt.

Die zweite Athletin (LSJ) nimmt an Wettbewerben in Rollstuhl-Korbball und Leichtathletik auf der Aschenbahn auf nationaler Ebene teil.

Die körperliche Dichtigkeit wurde durch den normalen Unterwasser-Wiegeprozeß und den zurückbleibenden Rauminhalt (Volumen) festgestellt.

Eine zweite Methode, die zellige Körpermasse festzustellen, war das Messen der Potassium 40 (40K)-Wirksamkeit durch den Ganzkörper-Flimmerzähler.

Die charakteristischen Kennzeichen dieser Athletinnen werden nachstehend wie folgt aufgeführt:

\begin{tabular}{cccccc}
\hline Subjekt & Alter & Gewicht $(\mathrm{kg})$ & $\begin{array}{c}\text { Größe }(\mathrm{cm}) \\
\text { sitzend }\end{array}$ & $\begin{array}{c}{ }^{\circ} \text { Fett } \\
40 \mathrm{~K}\end{array}$ & $\begin{array}{c}{ }_{0}^{\circ} \text { Fett } \\
\left(\mathrm{H}_{2} \mathrm{O}\right)\end{array}$ \\
\hline I & 25 & $50 \cdot 8$ & $87 \cdot 8$ & $29 \cdot 49$ & 28.94 \\
2 & 27 & $69 \cdot 8$ & $84 \cdot 2$ & $3 \mathrm{I} \cdot \mathrm{I} 2$ & $32 \cdot 08$ \\
\hline
\end{tabular}

Die Ergebnisse zeigen, daß beide Methoden, das Fettgewebe festzustellen, sich nur um eine Prozent voneinander unterscheiden.

Es ist wichtig, die Körperzusammensetzung dieser Rollstuhl-Athletinnen festzustellen, da ihre zellige Körpermasse durch ihre Behinderung vermindert ist.

\section{REFERENCES}

AKers, R. \& BuskiRK, E. R. (I969). An underwater weighing system utilizing 'force cube' transducers. F. Appl. Physiol, 26, 649-652.

Allen, T. H., Peng, M. T., Chan, K. B., Huang, T. F., Chang, C. \& Fang, H. S. (1956). Prediction of total adiposity from skinfolds and the curvilinear relationship between external and internal adiposity. Metab., 5, 346-353.

Behnke, A. R. \& Wilmore, J. H. (I974). Evaluation and Regulation of Body Build and Composition. Prentice-Hall, Inc., Englewood Cliffs, N.J.

Boileau, R. A., Massey, B. H. \& Misner, J. E. (I973). Body composition changes in adult men during selected weight training and jogging programs. Res. Quart., 44, I 58-168.

Brozek, J., Grande, F., Anderson, J. T. \& Keys, A. (I963). Densitometric analysis of body composition: Revision of some quantitative assumptions. Annals of the New York Academy of Sciences, II0, I I3-I40.

Cameron, J. R. \& Sorenson, J. A. (1963). Measurement of bone mineral in vivo: An improved method. Science, 140, 230-232.

Cohn, S. H., Vartsky, S. Y. \& SAwitsky, A. et al., (1980). Compartmental body composition based on total-body nitrogen, potassium and calcium. Am. F. Physiol., 239, $\mathrm{E}_{524}$.

Katch, F. I. \& MCARdLE, W. D. (I973). Prediction of body density from simple anthropometric measurements in college-age men and women. Hum. Biol., 45, $445-454$.

McARdLe, W. D., Katch, F. I. \& Katch, V. L. (I98I). Exercise Physiology, Lea \& Febiger, Philadelphia, PA.

SloAN, A. W., BURT, J. J. \& BLyth, C. S. (I962). Estimation of body fat in young women. 7. Appl. Physiol., I7, 967-970.

Twardock, A. R., Lohman, T. G. \& SMith, G. S. et al. (1966). The Illinois animal science counter. F. Animal Sci., 25, I209.

Vaccaro, P., Morris, A. F. \& Clarke, K. (I98I). Physiological characteristics of masters female distance runners. The Phys. Spts. Med., 9, I05.

WilmoRE, J. H. (I969). A simplified method for determination of residual lung volumes. 7. Appl. Physiol., 27, 96-100.

Wilmore, J. H. \& BehNKE, A. K. (I970). An anthropometric estimate of body density and lean body weight in young women. Am. F. Clin. Nutrit., 23, 267-274. 